\title{
ANALISIS KEMAMPUAN BERPIKIR CALON GURU DALAM MENYELESAIKAN PERMASALAHAN MATEMATIKA BERORIENTASI PADA HOTS
}

\author{
Maimunah $^{1}$, Finata Rastic Andrari ${ }^{2}$, Nurmala Dewi Qadarsih ${ }^{3}$ \\ Program Studi Teknik Informatika, Universitas Indraprasta PGRI ${ }^{1,2,3}$ \\ Email: maimunah@unindra.ac.id ${ }^{1}$
}

\begin{abstract}
Abstrak
Matematika adalah salah satu ilmu yang berperan penting dalam perkembangan ilmu pengetahuan, teknologi, dan kemajuan daya pikir manusia yang diberikan mulai dari tingkat pendidikan dasar sampai tingkat pendidikan tinggi agar siswa memiliki kemampuan berpikir logis, sistematis, analitis, kritis, kreatif dan memiliki kemampuan bekerja sama yang baik. Mahasiswa Pendidikan Matematika, sebagai calon guru diharapkan mampu menyelesaikan permasalahan yang mengukur HOTS dahulu agar kelak mampu membantu siswa menyelesaikan soal HOTS. Tujuan dari penelitian ini adalah untuk mendeskripsikan kemampuan berpikir calon guru dalam menyelesaikan permasalahan matematika berorientasi HOTS. Jenis penelitian yang digunakan adalah deskriptif kualitatif dengan subjek sebanyak 3 orang dari mahasiswa semester V Pendidikan Matematika Unindra PGRI yang terdiri dari subjek dalam kelompok rendah, sedang, dan tinggi yang masing-masing diwakili oleh 1 orang. Teknik analisis data yang digunakan adalah reduksi data, kategorisasi, sintesisasi, dan penyusunan hipotesis kerja. Hasil penelitian menunjukkan bahwa calon guru sudah mampu memecahkan permasalahan berorientasi HOTS pada tingkat menganalisis dan mengevaluasi. Dari ketiga subjek penelitian, ketiga subjek sudah mampu memenuhi indikator tingkat menganalisis dan mengevaluasi dengan cukup baik. Pada tingkat mengkreasi, hanya satu calon guru yang mampu memenuhi 2 dari 4 indikator mengkreasi yang ada. Sedangkan 2 calon guru lainnya hanya mampu memenuhi 1 dari 4 indikator tingkat mengkreasi.
\end{abstract}

Kata Kunci : Matematika, HOTS, Calon Guru

\begin{abstract}
Mathematics is one of the sciences that plays an important role in the development of science, technology, and the advancement of human thinking, starting from the basic education level to the higher education level so that students are ablet to think logically, systematically, analytically, critically, creatively and have the ability to work together. Mathematics Education students, as prospective teachers, are expected to be able to solve problems that measure HOTS in advance so that later they can help students solve the HOTS questions. This study aims to describe the thinking skills of prospective teachers in solving HOTS-oriented math problems. The type of research used was descriptive qualitative with 3 subjects from the fifth-semester students of Mathematics Education Unindra PGRI consisting of subjects in the low, medium, and high groups, each represented by 1 person. The data analysis techniques used were data reduction, categorization, synthesis, and the preparation of working hypotheses. The results showed that the prospective teachers were able to solve HOTS-oriented problems at the level of analyzing and evaluating. Of the three research subjects, the three subjects were able to meet the level indicators of analyzing and evaluating quite well. At the creative level, only one teacher candidate was able to meet 2 of the 4 existing creative indicators. Meanwhile, the other 2 prospective teachers were only able to meet 1 of the 4 creative level indicators.
\end{abstract}

Key Words : Mathematics, HOTS, Prospective Teachers

\section{PENDAHULUAN}

Matematika adalah salah satu ilmu yang berperan penting dalam perkembangan ilmu pengetahuan, teknologi, dan kemajuan daya pikir manusia yang diberikan mulai dari tingkat pendidikan dasar sampai kepada tingkat pendidikan tinggi sebagai bekal agar siswa memiliki 
kemampuan berpikir logis, sistematis, analitis, kritis, kreatif dan memiliki kemampuan bekerja sama yang baik. Pelajaran matematika dan permasalahan matematika yang diberikan bertujuan untuk melatih kemampuan berpikir dan mengetahui posisi tingkat berpikir karena pemecahan masalah matematika sangat dipengaruhi oleh tingkat kemampuan berpikir. Kemampuan berpikir merupakan proses berpikir yang tidak sekedar menghafal dan menyampaikan kembali informasi yang diketahui siswa [1].

Secara umum, kemampuan berpikir seseorang terdiri dari Lower Order Thinking Skills (LOTS) dan Higher Order Thinking Skilss (HOTS). Berdasarkan taksonomi Bloom hasil revisi, LOTS mencakup kemampuan mengingat, memahami dan mengaplikasikan, sedangkan HOTS mencakup kemampuan menganalisis, mengevaluasi, dan mencipta [2]. Walaupun termasuk dalam LOTS namun kemampuan mengingat, memahami dan mengaplikasikan sangat berpengaruh terhadap HOTS [3]. Ketiga kemampuan tersebut adalah sebagai dasar untuk membentuk HOTS. Dengan demikian, seseorang yang memiliki kemampuan sangat baik dalam mengerjakan soal-soal HOTS, akan cukup baik juga kemampuan mengerjakan persoalan LOTS.

Sebagai kemampuan berpikir, HOTS terdiri dari beberapa komponen. HOTS terdiri dari kemampuan berpikir kritis dan kemampuan berpikir kreatif [4]. Rincian HOTS dibagi ke dalam 13 keterampilan yaitu: 1) membandingkan; mengklasifikasikan; 3) menginduksikan; 4) mendeduksikan; 5) analisis kesalahan; 6) membangun pendukung; 7) menganalisis sudut pandang; 8) mengabstraksikan; 9) pembuatan keputusan; 10) menginvestigasi; 11) pemecahan masalah; 12) penyelidikan; 13 penemuan [5]. Kemampuan berpikir tingkat tinggi inilah yang menjadi sasaran pelaksanaan pembelajaran. Oleh karena itu dalam pembelajaran guru harus mampu mengarahkan dan melatih siswa agar memiliki kemampuan berpikir tingkat tinggi (HOTS).

Uraian di atas menjelaskan bahwa HOTS merupakan kemampuan seseorang dalam mengolah secara logis, kritis, dan kreatif pada suatu informasi sehingga dapat mengevaluasi dan memecahkan permasalahan yang dihadapi. Kemampuan HOTS ini muncul dan berkembang melalui kegiatan pemecahan suatu permasalah. Seseorang dapat mengaktifkan HOTS jika orang tersebut dihadapkan pada masalahmasalah yang tidak familiar [6]. Dengan HOTS seseorang dapat menjadi pemecah masalah yang baik. Hasil penelitian ini menunjukkan bahwa HOTS memberikan peran yang cukup signifikan dalam pembentukan dan peningkatan pemahanan siswa dalam pemecahan masalah matematis [7].

Peran HOTS yang signifikan tersebut menjadi indikasi bahwa siswa pada semua jenjang pendidikan perlu memiliki dan mengembangkan kemampuan HOTS-nya. Kemampuan ini juga diperlukan oleh calon guru matematika agar dapat memahami konsep-konsep matematika di jenjang Perguruan Tinggi. Oleh karena itu, menjadi penting sekali untuk menganalisis kemampuan calon guru dalam menyelesaikan permasalahan matematis berorientasi pada HOTS. Hasil analisis ini nantinya dapat menjadi acuan atau pedoman untuk para guru dalam meningkatkan HOTS di kelas. Lebih dari itu, penguasaan HOTS yang baik perlu dimiliki oleh calon guru agar dapat membimbing siswanya dalam mengembangkan HOTS.

Berdasarkan latar belakang yang telah disampaikan sebelumnya, tujuan dari 
penelitian ini adalah mendeskripsikan kemampuan berpikir tingkat tinggi calon guru dan memberikan gambaran mengenai bagaimana kemampuan berpikir tingkat tinggi calon guru dalam menyelesaikan permasalahan matematika yang berorientasi pada HOTS. Berdasarkan tujuan penelitian yang telah diuraikan tersebut, penelitian ini memberikan kontribusi dalam bidang pendidikan, di antaranya adalah hasil penilaian (assessment) kemampuan berpikir calon guru dalam menyelesaikan permasalahan matematika yang berorientasi pada HOTS yang didapatkan melalui tes kepada para calon guru. Gambaran hasil penilaian tersebut nantinya dapat dijadikan sebagai pertimbangan penggunaan beberapa media, atau metode pembelajaran yang dapat digunakan oleh guru dalam pembelajaran di kelas.

\section{METODE}

Penelitian ini adalah penelitian deskriptif dengan pendekatan kualitatif. Penelitian deskriptif merupakan penelitian yang bertujuan mendeskripsikan kondisi secara objektif [8]. Penelitian dengan data kualitatif adalah penelitian dengan data bentuk gambar, kalimat, dan kata [8]. Tujuan penelitian kualitatif adalah untuk menggambarkan dan mengungkapkan serta menjelaskan. Penelitian ini digunakan untuk mendeskripsikan kemampuan berpikir tingkat tinggi calon guru dalam menyelesaikan permasalahan geometri yang berorientasi pada HOTS, dan wawancara sebagai bentuk konfirmasi atas pengerjaan soal oleh calon guru.

Instrumen yang digunakan dalam penelitian adalah tes tertulis dan wawancara. Soal tes tertulis yang digunakan adalah soal tes uraian yang bertujuan untuk mengukur kemampuan berpikir tingkat tinggi subjek, dan instrumen Wawancara menggunakan pedoman wawancara yang digunakan untuk mengkonfirmasi hasil tes tertulis subjek yang kurang menyeluruh atau kurang bisa dipahami peneliti.

Aspek dan indikator yang digunakan peneliti dalam menganalisis kemampuan berpikir tingkat tinggi calon guru matematika sesuai pendapat yang menyatakan bahwa indikator yang mengukur kemampuan berpikir tingkat tinggi meliputi menganalisis, mengevaluasi, dan mengkreasi [9]. Proses analisis data dalam penelitian kualitatif ini menggunakan tahapan yang meliputi reduksi data, kategorisasi, sintesisasi, dan penyusunan hipotesis kerja [10].

Mereduksi data berarti menyimpulkan, memilah dan fokus pada hal-hal penting, mencari tema dan polanya, dan membuang yang tidak perlu [11]. Reduksi data dalam penelitian ini, yaitu memfokuskan pada calon guru yaitu mahasiswa pendidikan matematika semester $\mathrm{V}$ Unindra PGRI yang memiliki nilai IPK tertinggi dari tiap kelompok (rendah, sedang, dan tinggi) untuk kemudian diambil beberapa sebagai subjek penelitian yang akan dianalisis indikator HOTSnya.

Tujuan dari tahap kategorisasi dalam penelitian adalah untuk memilah setiap data yang memiliki kesamaan fokus permasalahan antara satu dengan yang lainnya. Kategorisasi juga masih menggunakan kode seperti halnya reduksi data yang kemudian dikenal dengan kategori. Setiap kategori diberi label atau nama.

Pada tahap sintesisasi, dicari keterkaitan atau perpaduan antar kategori yang ditemukan. Hal ini bertujuan untuk memberikan label terhadap data-data tersebut. Proses sintesisasi pada penelitian mengamati keterkaitan antara kategori yang diperoleh dengan aspek-aspek pada tingkatan kemampuan berpikir tingkat 
tinggi (HOTS). Hipotesis kerja digunakan untuk menjawab rumusan masalah penelitian. Hipotesis kerja dalam penelitian ini dapat dilihat pada analisis dan pembahasan yang ada.

\section{HASIL DAN PEMBAHASAN}

Pengambilan data dilaksanakan pada bulan Mei 2020 dengan diawali kegiatan observasi kelas penelitian terlebih dahulu. Pada tahap observasi, peneliti mengamati bagaimana proses pembelajaran dan bagaimana subjek belajar. Dari hasil observasi, diketahui bahwa subjek adalah calon guru matematika yaitu mahasiswamahasiswa pendidikan matematika semester V Unindra PGRI yang disiplin belajar dan memiliki nilai IPK yang tergolong baik (hal ini berdasarkan nilai IPK yang didapatkan peneliti dari subjek penelitian).

Selanjutnya dari keseluruhan jumlah subjek yaitu 20 orang, peneliti memfokuskan pada 3 subjek yang memiliki nilai IPK tertinggi pada kelompok rendah, sedang, dan tinggi yang masing-masing diwakili oleh 1 orang untuk kemudian diambil beberapa sebagai subjek penelitian yang akan dianalisis indikator HOTSnya. Setelah mengidentifikasi hasil pengerjaan mahasiswa calon guru, selanjutnya peneliti secara purposive menentukan 1 subjek dari tiap kelompok, kemudian dengan mengacu pada tahapan analisis data, peneliti menganalisis kemampuan ketiga subjek penelitian secara kualitatif [10].

Tabel 1 memperlihatkan bahwa pada level mengkreasi, dari 10 orang subjek penelitian tersebut, tidak satu orangpun yang mampu memecahkan permasalahan matematika yang diberikan dengan tepat.

Hasil analisis kemapuan berpikir calon guru matematika dalam menyelesaikan permasalahan berorientasi HOTS disajikan pada Tabel 2.

Tabel 1. Jumlah Subjek yang Mengerjakan Permasalahan Berorientasi HOTS dengan Jumlah Subjek yang Mengerjakan dengan Tepat

\begin{tabular}{|c|c|c|c|}
\hline Level & Indikator & $\begin{array}{l}\text { Jumlah yang } \\
\text { Mengerjakan }\end{array}$ & $\begin{array}{c}\text { Jumlah yang Menyelesaikan } \\
\text { dengan Tepat }\end{array}$ \\
\hline \multirow{4}{*}{$\begin{array}{l}\text { Analisis } \\
\text { (C4) }\end{array}$} & Memberi Atribut & 20 & 13 \\
\hline & Mengorganisasikan & 19 & 10 \\
\hline & Mengintegrasi & 20 & 13 \\
\hline & Mensahihkan & & \\
\hline \multirow{4}{*}{$\begin{array}{l}\text { Evaluasi } \\
\quad \text { (C5) }\end{array}$} & Mengecek & 16 & 4 \\
\hline & Mengkritisi & & \\
\hline & Mengajukan Hipotesis & & \\
\hline & Melakukan Eksperimen & & \\
\hline \multirow[t]{4}{*}{ Kreasi (C5) } & Mengeneralisasikan & 10 & 0 \\
\hline & Merancang & & \\
\hline & Memproduksi & & \\
\hline & Merancang Kembali & & \\
\hline
\end{tabular}

Berdasarkan hasil penelitian yang telah disajikan sebelumnya, dapat diketahui bahwa penelitian mengenai analisis kemampuan berpikir tingkat tinggi calon guru matematika dalam menyelesaikan masalah berorientasi HOTS menunjukkan bahwa pada level mengkreasi, hanya 10 dari 20 mahasiswa yang mencoba menyelesaikan permasalahan matematika yang diberikan (Tabel 1). Kemudian dari 10 orang tersebut, tidak satu orangpun yang mampu memecahkan permasalahan matematika pada level mengkreasi yang diberikan dengan tepat (Tabel 2). Hal ini 
disebabkan karena level mengkreasi adalah level tertinggi dalam HOTS dan permasalahan matematika yang diberikan dalam penelitian adalah mengenai permasalahan geometri. Ini sejalan dengan pendapat yang menyatakan bahwa dalam belajar geometri memerlukan HOTS [12].

Hasil penelitian menjelaskan bahwa pada umumnya, masih lemahnya kemampuan berpikir geometris mahasiswa dalam memvisualisasi, menganalisis, dan mengabstraksi adalah penyebab kesulitan mahasiswa dalam mengerjakan masalah geometri [12]. Dalam penelitian ini, kurangnya kemampuan mahasiswa dalam permasalahan geometri dan pengukuran pada kelompok rendah dan sedang disebabkan oleh kemampuan visual spasial para mahasiswa yang juga masih rendah. Kemampuan visual spasial sangat berkaitan dengan pengenalan visual, perbedaan visual, pertimbangan ruang, manipulasi gambar, dan duplikasi dari gambaran internal ataupun eksternal yang saling terkait dan dapat diekspresikan [13]. Rendahnya kemampuan visual spasial dapat dilihat melalui kurangnya kemampuan mahasiswa dalam memahami gambar dan menentukan konsep-konsep matematis yang sesuai dan perlu dikaitkan untuk memecahkan masalah tersebut.

Tabel 2. Persentase Kemampuan Berpikir Calon Guru dalam Menyelesaikan Permasalahan Berorientasi HOTS

\begin{tabular}{clccc}
\hline Level HOTS Indikator & \multicolumn{1}{c}{ S1 } & S2 & S3 \\
\hline 1 & Memberikan Atribut & $\sqrt{ }$ & $\sqrt{ }$ & $\sqrt{ }$ \\
& Mengorganisasikan & $\sqrt{ }$ & $\sqrt{ }$ & - \\
& Mengintegrasikan & $\sqrt{ }$ & $\sqrt{ }$ & $\sqrt{ }$ \\
& Mensahihkan & $\sqrt{ }$ & $\sqrt{ }$ & 3 \\
& Jumlah & 4 & 4 & $75 \%$ \\
2 & Rata-rata total & $100 \%$ & $100 \%$ & $\sqrt{ }$ \\
& Mengecek & $\sqrt{ }$ & $\sqrt{ }$ & $\sqrt{ }$ \\
& Mengkritisi & $\sqrt{ }$ & $\sqrt{ }$ & $\sqrt{ }$ \\
& Mengajukan hipotesis & $\sqrt{ }$ & $\sqrt{ }$ & 4 \\
& Melakukan eksperimen & $\sqrt{ }$ & 4 & $100 \%$ \\
& Jumlah & 4 & $100 \%$ & - \\
& Rata-rata total & $100 \%$ & $\sqrt{ }$ & - \\
& Menggeneralisasi & $\sqrt{ }$ & - & - \\
& Merancang & - & - & 1 \\
& Memproduksi & - & - & $25 \%$ \\
\hline
\end{tabular}

Pada tingkat menganalisis yang disajikan dalam permasalahan nomor 1,2 , dan 3, dua subjek (S1 dan S2) sudah mampu memenuhi semua indikator pada tingkat menganalisis yaitu sebesar $100 \%$, Indikator tersebut terdiri dari memberikan atribut, mengorgnisasikan, mengintegrasikan, dan mensahihkan. Sedangkan subjek S3 hanya mampu memenuhi 3 indikator tingkat menganalisis sebesar 75\%, indikator tersebut terdiri dari memberikan atribut, mengintegrasikan, dan mensahihkan.
Secara keseluruhan, kemampuan ketiga subjek pada tingkat menganalisis sudah cukup baik. Meskipun S3 belum mampu memenuhi keempat indikator pada tingkat menganalisis yang ada, ini menunjukkan bahwa ketiga subjek tersebut sudah mampu memeriksa dan menguraikan informasi yang diberikan dan membagi-bagi informasi tersebut ke dalam bagian yang lebih sederhana untuk kemudian dicari pola dan hubungannya. Hal ini sejalan pendapat yang menjelaskan bahwa 
menganalisis adalah melibatkan proses memecah-mecah materi menjadi bagianbagian kecil dan menentukan bagaimana hubungan antar bagian dan struktur keseluruhannya [9]. Berdasarkan teori ini, secara umum subjek S1, S2, dan S3 sudah mampu menganalisis permasalahan yang diberikan.

Pada tingkat mengevaluasi yang disajikan pada permasalahan nomor 4, ketiga subjek (S1, S2, dan S3) sudah mampu memenuhi semua indikator mengevaluasi yaitu sebesar $100 \%$. Indikator tersebut terdiri dari mengecek, mengkritisi, dan mengajukan hipotesis. Ini menunjukkan bahwa ketiga subjek mampu memahami perintah pada permasalahan yang diberikan dengan baik. Ketiga subjek cukup mampu menilai, menyangkal ataupun mendukung suatu gagasan dan memberikan alasan yang mampu memperkuat jawaban yang diperoleh, merumuskan hipotesis, mengkritik, dan melakukan pengujian hipotesis. Kemampuan mengevaluasi dapat dilakukan apabila subjek menganalisis informasi yang didapat dengan tepat, memahami maksud pertanyaan dengan benar, serta memberikan alasan/bukti yang akurat. Berdasarkan hasil wawancara (WES1, WES2, dan WES3) didapatkan penjelasan bahwa ketiga subjek juga cukup mampu menilai, menyangkal ataupun mendukung suatu gagasan dan memberikan alasan yang mampu memperkuat jawaban yang diperoleh, merumuskan hipotesis, mengkritik, dan melakukan pengujian hipotesis yang diberikan. Hal ini sejalan dengan pernyataan yang menyatakan bahwa mengevaluasi adalah membuat keputusan berdasarkan kriteria dan standar [9]. Dapat disimpulkan bahwa pada indikator soal mengevaluasi ketiga subjek sudah mampu untuk membuat keputusan berdasarkan kriteria-kriteria yang telah dirumuskan dalam permasalahan yang diberikan.
Pada tingkat mengkreasi, hanya satu subjek (S1) yang mampu memenuhi 2 indikator tingkat mengkreasi dari 4 indikator yang ada. Sedangkan dua subjek lainnya (S2 dan S3) hanya mampu memenuhi 1 indikator tingkat mengkreasi dari 4 indikator yang ada. Artinya, tidak ada satupun subjek yang mampu memenuhi 4 indikator pada tingkat mengkreasi. Rendahnya kemampuan mengkreasi ini disebabkan karena mengkreasi adalah level tertinggi dalam kemampuan berpikir tingkat tinggi. Pada permasalahan yang diberikan, tidak diberikan petunjuk tampilan berupa gambar apapun, hal ini menyebabkan ketiga subjek mengalami kesulitan dalam menganalisis dan mengevaluasi permasalahan tersebut. Mencipta adalah proses menyusun elemen-elemen menjadi sebuah keseluruhan yang yang fungsional dan kohern [9]. Berdasarkan teori yang dikemukakan pada indikator mengkreasi, subjek belum mampu untuk menyusun elemen-elemen yang diketahui untuk membuat model secara umum yang memenuhi untuk semua kemungkinan. Oleh karena itu, pada indikator mengkreasi kategori berpikir tingkat tinggi yang diperoleh masih sangat rendah.

\section{SIMPULAN}

Hasil penelitian menunjukkan bahwa calon guru pendidikan matematika Unindra PGRI sudah mampu memecahkan permasalahan berorientasi HOTS pada tingkat menganalisis dan mengevaluasi. Dari ketiga subjek penelitian, ketiga subjek sudah mampu memenuhi indikator tingkat menganalisis dan mengevaluasi dengan cukup baik. Pada tingkat mengkreasi, hanya satu calon guru yang mampu memenuhi 2 indikator tingkat mengkreasi dari 4 indikator yang ada. Sedangkan 2 calon guru lainnya hanya mampu memenuhi 1 indokator dari 4 indikator tingkat mengkeasi. 


\section{DAFTAR PUSTAKA}

[1] W. P. Ardiandari. "Mengintegrasikan Higher Order Thinking dalam Pembelajaran Creative Problem Solving”. Seminar Nasional Matematika UNY, 2015.

[2] K. Suryapuspitarini, B. W. Wardono, dan K. Kartono. "Analisis Soal-Soal Matematika Tipe Higher Order Thinking Skill (HOTS) pada Kurikulum 2013 untuk Mendukung Kemampuan Literasi Siswa”. Prosiding Seminar Nasional Matematika, 2018, pp. 876-884.

[3] B. Wicasari dan Z. Ernaningsih. "Analisis Kemampuan Berpikir Siswa dalam Menyelesaikan Permasalahan Matematika yang Berorientasi pada HOTS". Prosiding Seminar Nasional Reforming Pedagogy, 2016, pp. 249-254.

[4] W. B. N. Dosinaeng. "Analysis of Student's Higher Order Thinking Skills in Solving Basic Combinatorics Problems". Math Didact. J. Pendidik. Mat., vol. 9, no. 2, pp. 133-147, 2019.

[5] Y. M. Heong, W. B. Othman, J. B. M. Yunos, T. T. Kiong, R. B. Hassan, and M. M. B. Mohamad. "The Level of Marzano Higher Order Thinking Skills among Technical Education Students". Int. J. Soc. Sci. Humanit., vol. 1, no. 2, pp. 121-125, 2011.
[6] B. Tanujaya, J. Mumu, and G. Margono. "The Relationship between Higher Order Thinking Skills and Academic Performance of Student in Mathematics Instruction". Int. Educ. Stud., vol. 10, no. 11, pp. 78-85, 2017.

[7] N. A. M. Tajudin. "The Link Between Higher Order Thinking Skills, Representation and Concepts in Enhancing TIMSS Task". Int. J. Instr., vol. 10, no. 11, pp. 78-85, 2016.

[8] A. Kurniawan. Metodologi Penelitian Pendidikan. Cirebon: PT Remaja Rosdakarya, 2018.

[9] L. Anderson and D. Krathwohl. Kerangka Pembelajaran, Pengajaran dan Assesemen. Yogyakarta: Pustaka Pelajar, 2015.

[10] L. Moleong. Metode Penelitian Kualitatif. Bandung: PT. Remaja Rosdakarya, 2009.

[11] Sugiyono. Metode Peneltian Pendidikan. Bandung: Alfabeta, 2015.

[12] H. Budiman. "Analisis Kemmapuan Berpikir Geometri Mahasiswa Pendidikan Matematika". J. Prism., vol. 4, no. 8, pp. 28-40, 2015.

[13] M. Fadhli. Merangsang Kecerdasan Visual Spasial Anak Usia Dini dengan Media Video Universitas Muhammadiyah Ponorogo. Malang: IKIP Malang, 2016. 